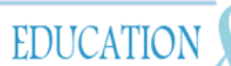

Research, Innovation and Solutions on-line ${ }^{3}$
PSYCHOLOGY

$1+D+i$
Electronic Journal of Research

in Educational Psychology

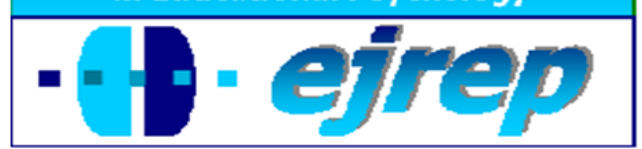

\title{
Teacher-related factors as correlates of pupils' achievement in Social Studies in Southwestern Nigeria
}

\author{
Babatunde Adeyemi
}

Faculty of Education, Obafemi Awolowo University, Ile-Ife

Nigeria

Correspondence: Babatunde Adeyemi. Institute of Education, Faculty of Education, Obafemi Awolowo University, Ile-Ife, Nigeria. E-mail: adeyemibabs2003@yahoo.com

(C) Education \& Psychology I+D+i and Editorial EOS (Spain) 


\begin{abstract}
Introduction. The teacher plays a significant role in the intellectual development of the pupils, using various assessment and teaching styles to improve pupils' performance in school subjects. The study therefore investigated the effect of some teacher related factors: teacher level of awareness of assessment style, teacher assessment style, teacher personal characteristics (qualification, year of experience and teaching styles) on pupils' achievement in Social Studies in primary schools.
\end{abstract}

Method. The study was a correlational type. Multi-stage sampling technique was employed in selecting three states from the existing six states that constitute Southwestern zone in Nigeria. Three instruments were used in the study. Three research questions emanated from the study and were analysed using mean, standard deviation, graphical illustration and multiple regression analysis.

Results. Results revealed that Social Studies teachers engaged more in formal authority and facilitation teaching styles. There was a significant relationship among teacher related factors and pupils' achievement in Social Studies. Only two predictors had significant relative effect on pupils' achievement in Social Studies.

Discussion and Conclusion. Based on these findings, teaching and assessment styles of teachers are crucial in the learning of Social Studies. Workshops and seminars should therefore be organized for teachers on various teaching styles.

Keywords: Primary Education, teachers's styles, achievement, assessment.

Received: 09/28/09 Initial Acceptance: 09/30/09 Definitive Acceptance: 02/19/10 


\section{Factores del profesorado que correlacionan con el logro del alumnado en Estudios Sociales del Sudoeste de Nigeria}

\section{Resumen}

Introducción. El profesorado juega un papel significativo en el desarrollo intelectual del alumnado a través de los procesos de evaluación y de los estilos educativos que mejoran el rendimiento. Este estudio investiga el efecto de algunos factores relacionados con el profesorado tales como, el nivel de concienciación hacia la metodología de evaluación, el estilo evaluativo y las características personales (cualificación, experiencias, estilo educativo) sobre el rendimiento del alumnado de escuelas primarias en la asignatura de Estudios Sociales.

Método. El estudio sigue un diseño correlacional. La técnica de muestreo estratificado es utilizada en la selección de la muestra de tres estados de los seis existentes que constituyen la zona sudoeste de Nigeria. Tres instrumentos se utilizan en el estudio. Las cuestiones de investigación emanan de la naturaleza del estudio y se analizan utilizando medidas tales como la media, la desviación estándar, y análisis de regresión múltiple

Resultados. Los resultados señalan que el profesorado de Estudios Sociales se identifica con estilos de autoridad formal y de facilitación. Existe una relación significativa entre los factores relativos al profesorado y el rendimiento del alumnado. Sólo dos Predictores tienen efectos significativos en el rendimiento del alumnado de Estudios Sociales.

Discusión y conclusiones. Basados en los resultados anteriores, los estilos de enseñanza y evaluación del profesorado resultan cruciales en la asignatura de Estudios Sociales. Talles y seminarios para el profesorado deberían organizarse y trabajar los estilos educativos.

Palabras Clave: Educación Primaria, estilos docentes, rendimiento, evaluación.

Recibido: 28/09/09 Aceptación Inicial: 30/09/09 Aceptación Definitiva: 19/02/10 


\section{Introduction}

Primary education, as described in the FRN, National Policy on Education, (Revised 2004) is the education given in institutions for children from ages 6-11 years plus. Since the rest of the education system is built upon it, primary level is the key to the success or failure of the whole system. According to the National Policy on Education (2004), the goals of primary education are to:

a. Inculcate permanent literacy and numeracy and ability to communicate effectively;

b. Lay a sound basis for scientific and reflective thinking;

c. Give citizenship education as a basis for effective participation in and contribution to society;

d. Mould the character and develop sound attitude and morals in the child;

e. Develop the child ability to help him adapt to his changing environment;

f. Give the child opportunity of developing manipulative skills that will enable him to function effectively in the society within the limits of his capacity; and

g. Provide the child with basic tools for further educational advancement, including preparation for trades and crafts of the locality.

Since the National Policy on Education is the government's way of facilitating that part of its national objectives that can be achieved using education as a tool, no education policy can be formulated without first identifying the overall philosophy and objectives of the nation. The five main objectives as stated in the Second National Development Plan, and endorsed as the necessary foundation for the National Policy on education, are to establish:
a. A free and democratic society;
b. A just and egalitarian society,
c. A united, strong and self-reliant nation;
d. A great and dynamic economy; and
e. A land full of bright opportunities for all citizens.

For the philosophy to be in harmony with Nigeria's national objectives, it has to be geared towards self-realization, better human relationships, individual and national efficiency, effective citizenship, national consciousness, national unity, as well as towards social, cultural, political, scientific and technological progress. To achieve the above objectives, the teacher assumes an enviable position in the curriculum implementation at any level. Ukeje 
(1991) maintained that it is the teacher that 'translates policies and programmes into action'. Lassa,(1996) also stated that the teacher is the initiator of the learning process, the facilitator of the learning skills, the coordinator of the learning sequences, the assessor of the learning efficiency, and indeed the pivotal element in the entire educational development.

The importance of Social Studies teaching at the Primary school level is predicted on Brunner's (1963) assertion that any subject can be taught effectively in some intellectually honest form to any child at any stage of development, if adequately and relevantly structured. This suggests that every discipline has a structure which is made up of some fundamental concepts and generalization peculiar to it. Social studies teaching in the primary school will lead to the achievement of the third objective which is the basis for effective participation, and contribution to the good of the society.

Most teachers in schools today have no clear idea of what "interactive whole-class teaching style is and have received little practical guidance on implementing it" (Primary Schools and Literacy, 2003). According to Cuban (1984), one way of finding how teachers taught over a period of time is to examine if instruction has been teacher centered or student centered or a mixture of the two in varying degrees. According to him, a teacher-centered instruction, means that a teacher controls what is taught, when, and under what conditions within his or her classroom. Also, a "student-centered instruction means that students exercise a substantial degree of direction and responsibility for what is taught, how it is learned, and for any movement within the classroom". The following criteria determine the dominant forms of instruction in a classroom that can enable us determine, on a continuum, if instruction is teacher-centered or student-centered or somewhere between the two:

1 Arrangement of classroom space;

2 Ratio of teacher to student talk;

3 Whether most instruction occurs individually, in small groups, or with the entire class;

4 The presence of learning or interest centers that are used by students as part of the normal school day; and

5 The degree of movement students are permitted without asking the teacher (Cuban, 1984, p.5) 
The above position further shows the invaluable importance of teacher related factors to effective teaching and learning. It is therefore certain that students/pupils would not benefit much from learning, where teachers are not competent. Lawani (2004) quoting Ajayi(1996) reiterated that classroom teachers are one of the chief determinants of educational achievement: their academic qualification, relevant professional training, working experience among others are most significant determinants of students' academic performance.

One of the variables considered in this study is teachers' awareness level of assessment style, which could be described as a complex concept comprising both conscious and unconscious powers and sensitivities which enable a teacher to act creatively. Hence, to be a trained teacher involves the refinement and development of complex awareness. In this regard, Osunde and Ughamadu (2004) were of the view that there should be intensive and regular in-service training for all teachers in the school system, which should be carried out through induction courses/seminars and workshops with the prime purpose of introducing them to various assessment styles for effective implementation of assessment programme in Nigerian schools.

In the area of assessment technique, a teacher is expected to organise curriculum and teaching with the aim of helping children to overcome barriers to learning. On the other hand, assessment as the name implies, is the process of organizing test data into interpretable forms. The process of assessing pupils' performance is done by using a variety of techniques among which testing is one. In general, several tests of different types and testing different aspects of the child (Cognitive, Psychomotor, and affective) are needed in order to complete an assessment. In other words, the assessment of learning focuses on important factors and a number of measurement methods or techniques in order to arrive at a mark or judgment of pupils' ability, attitude and progress in a particular subject. Such multi-dimensional approaches may include tests, interviews, projects of homework, assignments, etc.

According to Qualification and Curriculum Authority (QCA) (2003), assessment for learning 'involves the use of classroom assessment to improve learning' and goes on to list the central features peculiar to assessment:

- embeds the teaching and learning process;

- $\quad$ shares learning goals with pupils;

- helps pupils to know and to recognize the standards to aim for; 
- provides feedback which leads pupils to identify what they should do next to improve;

- involves both teacher and pupils reviewing and reflecting on pupils' performance and progress; and

- involves pupils in self-assessment.

To this end, teachers usually use various means of getting information in a comprehensive way about a child before bringing their professional judgement to bear. Teacher needs to come to a decision, but that decision should come from all the knowledge that teacher has accumulated through collection, recording and retrieval of information that is important about a child's progress in relation to assessment and teaching. As a result of classroom assessment technique both teacher and students are empowered to improve the quality of learning in the classroom.

No wonder Osunde (2005) opined that a teacher needs a variety of instruments and techniques to assess the cognitive and non-cognitive (Affective and Psychomotor) behaviours of the students. The instruments include: Test, project, assignments, interview, rating scale, observation, questionnaire, anecdotal records and sociometric technique. Some of the instruments, according to him, are appropriate for the assessment of cognitive behaviours while others are useful for the assessment of affective and psychomotor behaviours. Also, Osunde and Ughamadu (2004) while discussing problems associated with assessment techniques in schools were of the view that the problems could be attributed to (i) variation in the assessment techniques being used in schools; and (ii) variation in the procedures for scoring and grading of the different assessment techniques in different schools. It is therefore a common knowledge that the standard of all assessments by different teachers across the country, states, and local government areas cannot be assumed to be the same.

In another study, Okwuanaso and Okeke (2005) conclude that the primary aim of assessment is to foster learning of worth for all students. To them, teachers should develop classroom assessments that value the ability to apply knowledge by reasoning and solving novel problems as well as the acquisition of knowledge and skills. Teachers should also evaluate their own classroom assessment practices and instructional procedures and how they affect students' achievement. It is in line with this view that the Bureau of Evaluative Studies and Testing (2007) itemized how teachers could employ assessment techniques. These include: 
- Provide short-term feedback about the day-to-day learning and teaching process at a time when it is still possible to make midcourse corrections;

- Provide useful information about student learning with a much lower investment of time compared to tests, papers, and other traditional means of learning assessment;

- Help to foster good rapport with students and increase the efficacy of teaching and learning; and

- Encourage the view that teaching is a formative process that evolves over time with feedback.

On teachers' personal characteristics, it could be said that teaching entails engaging students/pupils as active learners to induce positive comprehensive changes in their preexisting knowledge, skills and attitude. These are achieved by teachers who are able to build on learners' experiences, abilities, interests, motivation and skills. Therefore, teachers must have mastered the basic skills of teaching and possessed the ability to continuously adjust their teaching strategies to meet the diverse needs of their students/pupils. This entails knowledge of subject matter, skill in planning, skill in adapting to change, skill in assessment, professional responsibility, interpersonal skill and so on. Commenting on this characteristic Adegboye (2003) opined that Mathematics curriculum developers should involve the classroom teachers in future curriculum project right from the beginning to the end. To him, teachers should have imput in curriculum development. This will go a long way in assisting teachers in skill development.

In the same vein, Beldon, Russonello and Stewart (2004) while reporting the 2002 survey of educators in Ohio, focused on the quality of teaching and ways to improve teaching and learning from the point of view of teachers, school board members, professors in schools of education and administrators, itemized the following qualities of good teachers:

- Personal qualities of the individuals, including communication and people skills, passion and commitment, flexibility, and being a hard worker and team player.

- Knowledge and practical skills both in subject matter and pedagogy, particularly content knowledge and classroom experience.

- Committed to and love for children, respect them, and want to be with them. 
There is no doubt that the teaching certificate that teachers have will go a long way in effecting changes in their style of teaching as well as the mode of assessment they employed. Several studies have found a positive effect of teachers' qualification on learning. National Center for Education Statistics (2005) reported teaching and teaching-related behaviour among 1999 - 2000 bachelor's degree recipients as of 2001 when the study was carried out. This report attempts to look beyond the rate at which new graduates enter teaching by examining the categories of demographic characteristics, undergraduate teaching experiences, institutions attended, college entrance examination (CEE) scores and undergraduate grades, major or field of study, teaching-related experiences, characteristics of first-teaching jobs, and satisfaction and support at most-recent teaching jobs. The study found that, as long as the institution attended was non-doctoral granting, the percentage of those graduates who taught immediately following graduation was the same for those who entered immediately into a four-year program as those who entered into an associates or two-year program $(12 \%$ and $13 \%$ respectively), and that undergraduate GPA correlated with teacher licensure exam scores; while college entrance examination scores correlated negatively with teacher licensure scores.

\section{Research Questions}

The following research questions were answered in this study:

1. What is the teaching style of primary school teachers in Social Studies?

2. What is the composite effect of some teacher related factors: teacher awareness level of assessment style, teacher assessment style, teacher's personal characteristics (qualification, year of experience and teaching styles) on pupils' achievement in Social Studies?

3. What are the relative effects of some teacher related factors: teacher awareness level of assessment style, teacher assessment style, teacher personal characteristics (qualification, year of experience and teaching styles) on pupils' achievement in Social Studies? 


\section{Method}

\section{Participants}

The target population for this study comprised all public primary school pupils and their teachers in South Western States of Nigeria. Multi stage sampling technique was employed in selecting three States from the existing six states that constitute South Western zone in Nigeria. Five (5) local government areas were randomly selected from each of the selected three states of the South Western Nigeria. Ten (10) schools were randomly selected from each of the selected L.G.As. An intact class of an arm of primary 5 was randomly selected from each of the selected schools. All the pupils and their respective Social Studies teachers in the selected classes constituted the sample for this study. The sample consisted of three (3) states, fifteen (15) local governments, one hundred and fifty (150) schools, three thousand, three hundred and seven (3307) primary five pupils and four hundred and twenty five (425) Social Studies teachers.

Table 1 shows both the dependent and independent variables in the study.

Table1. Showing dependent and independent variables

\begin{tabular}{ll}
\hline \multicolumn{1}{c}{ Independent variables } & \multicolumn{1}{c}{ Dependent variables } \\
\hline Teacher related factors & Achievement scores in Social Studies. \\
- Teacher awareness level of assessment & \\
- style. & \\
- Teacher assessment style & \\
Teacher personal characteristics & \\
- Qualification & \\
- Year of experience and & \\
- Teaching style & \\
\hline
\end{tabular}

\section{Instrument}

Three (3) instruments were used in the study namely:

1. Social Studies Achievement Test (SSAT).

2. Teaching Style Survey Scale (TSSS)

3. Teacher Assessment Style Questionnaire (TASQ) 


\section{Social Studies Achievement Test (SSAT)}

The instrument (SSAT) was adopted from NECO past questions that were already standardized. The initial version of the items selected consisted of 40 items in Social Studies. Each item has one correct option and four distracters. Some items were discarded through item analysis. 20 items were retained. Kuder-Richardson formula 20 was used to establish internal consistency of the instrument which yielded 0.78 and the difficulty index (p) ranges from 0.4 to 0.6 .

\section{Teaching Style Survey Scale (TSSS)}

The instrument was adopted from Graham Reichmann (1996) teaching style. It was a standardized instrument comprising forty items. The instrument assisted in knowing the teaching style of teachers. It is a rating scale instrument of four options ranging from 'strongly disagree' to 'strongly agree' in such a way that $\mathrm{SD}=1, \mathrm{D}=2, \mathrm{~A}=3$ and $\mathrm{SA}=4$. The items consist of four categories of teaching styles, of which Formal Authority has eleven (11) items $(1,7,8,11,16,17,21,27,32,33$ and 36). Demonstrator has ten (10) items $(2,3,6,13,18,22,26,31,38$ and 39). Facilitator has ten (10) items $(4,9,10,12,14,19,23,28,37$ and $40)$ and Delegator has nine (9) items $(5,15,20,24,25,29,30,34$ and 35$)$. The maximum point for Formal Authority is 44 points, Demonstrator is 40 points, Facilitator is 40 points and Delegator is 36 points. However, the total scoring obtained in each category provided basis for classifying the teaching style of teachers. The instrument was revalidated based on environment in which the instrument was to be used. The instrument was administered on thirty teachers in two primary schools in Ekiti State, Nigeria. The reliability coefficient was established through Cronbach Alpha and the reliability index yielded 0.89.

\section{Teacher Assessment Style Questionnaire (TASQ)}

Teachers Assessment Style Questionnaire (TASQ) was developed by the author. The TASQ was used to elicit information on teachers as regards the technique of assessment they are using in eliciting feedback from pupils. TASQ consists of six sections, section A consists of eight items of personal information of the teachers. Section B deals with series of mode of assessment in which the teachers are expected to indicate their awareness, usage and period of usage. Section $\mathrm{C}$ is of two types which are open ended in nature. Teachers are expected to 
state reasons for using the ticked mode of assessment and also reasons for not using the ones not ticked. Section D involves series of mode of assessment in which teachers are expected to arrange in order of usage. Section $\mathrm{E}$ is of three levels in which teachers are expected to indicate the aspect(s) of behaviour they assess in pupils by ticking the appropriate one while section $\mathrm{F}$ is an open ended form in which teachers are expected to suggest ways of improving mode of assessment.

TAQ that was initially constructed was scrutinized by experts in Educational Evaluation and some items discarded. The final item was empirically validated to a sample of forty teachers and Cronbach coefficient Alpha was computed to determine the internal consistency reliability and a reliability value of 0.82 was obtained.

\section{Procedure}

The author trained six (6) other research assistants who were knowledgeable enough to master the technicalities of using the instrument to collect the required data. The author and the assistants directly used the instruments to collect the required data. Data collection lasted for about four (4) weeks.

\section{Design and Statistical Analysis}

The study is a correlational type. This is so because the author is interested in investigating possible relationships among variables without manipulating the variables. The data collected were subjected to both descriptive and inferential statistics with the use of the following statistical methods such as mean, Standard Deviation, graphical illustration, and Multiple Regression Analysis.

\section{Results}

Question One. What is the teaching style of primary school teachers in Social Studies?

Table 2 and figure 1 show the mean scores and standard deviations of primary school Social Studies teachers on teaching styles. The mean scores of Social Studies teachers on 
teaching styles are: Formal Authority $=30.45, \mathrm{SD}=8.11$; Demonstration $=28.36, \mathrm{SD}=7.94$; Facilitation $=29.14, \mathrm{SD}=7.84$; Delegation $=22.38, \mathrm{SD}=6.82$.

Table 2. Teaching styles of Primary School Teachers

\begin{tabular}{cccccc} 
& & Formal Authority & Demonstrator & Facilitator & Delegator \\
\hline Social & Mean & 30.45 & 28.36 & 29.14 & 22.38 \\
\cline { 2 - 6 } Studies & Std Deviation & 8.11 & 7.94 & 7.84 & 6.82 \\
\hline
\end{tabular}

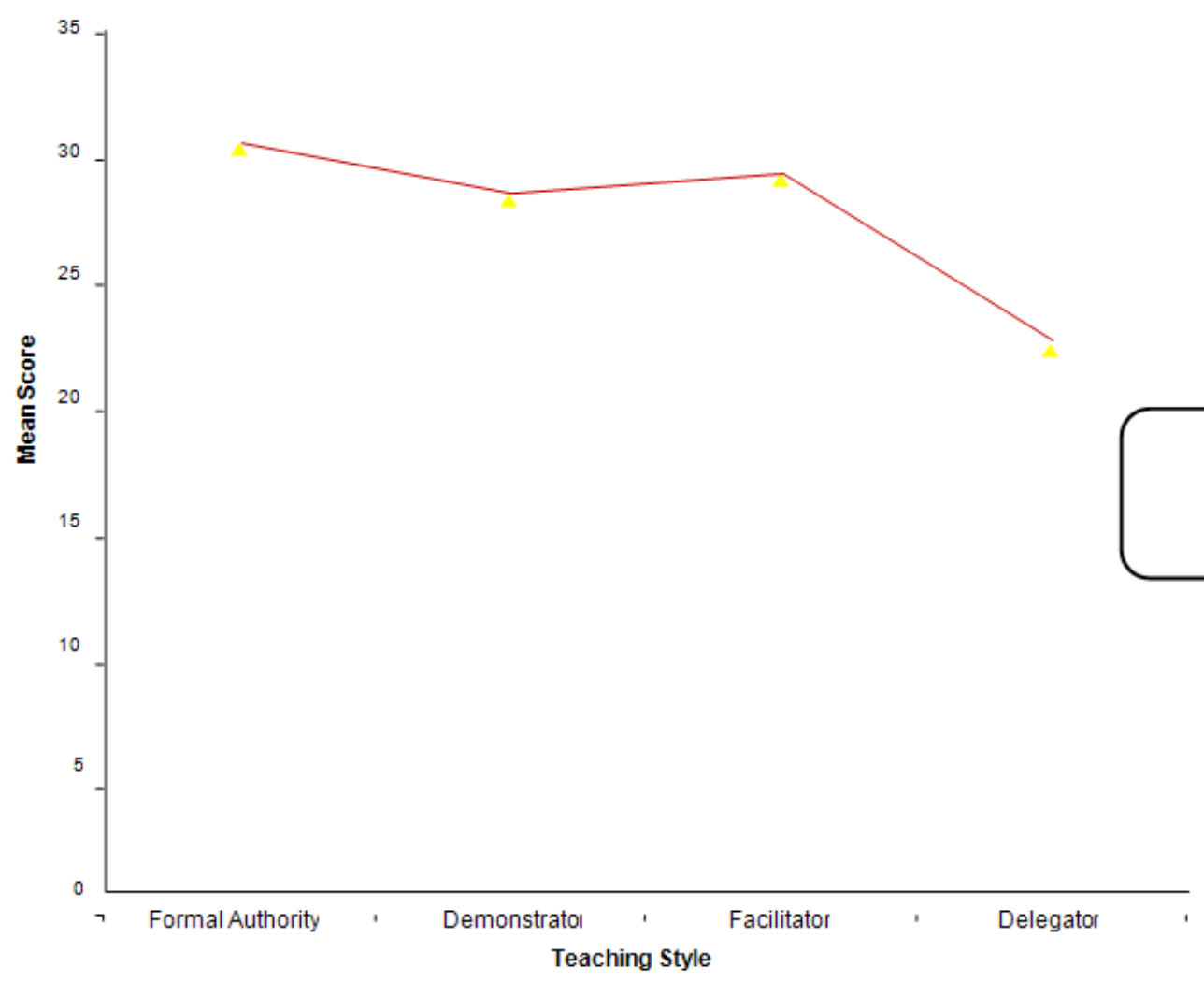

Figure 1. Teaching Style of Primary School Social Studies Teachers

Question Two: What is the composite effect of some teacher related factors: teachers' awareness level of assessment style, teacher assessment style, teacher personal characteristics (educational qualification and year of experience) and teaching styles on pupils' achievement in Social Studies?

Table 3 shows that the multiple regression correlation coefficient $(\mathrm{R})$ indicating the linear relationship between teacher factor and pupils' achievement in Social Studies is 0.258. The estimated adjusted $\mathrm{R}$ square equals 0.049 . This implies that all the teacher factors 
(awareness level of assessment style, assessment style, educational qualification, year of experience and teaching styles) when taken together accounted for 4.9 percent variation in pupils' achievement in Social Studies.

Further verification using multiple regression ANOVA, however, produced $\mathrm{F}-$ ratio $=$ 3.707; $\mathrm{P}<0.05$. This implies that there is a significant linear relationship between the teachers' related factors and pupils' achievement in Social Studies.

Table 3. Multiple Regression of Teacher related factors on Pupils' Achievement in Social Studies

\begin{tabular}{ll}
\hline Parameter & Value \\
\hline Multiple Regression (R) & .258 \\
R square & .067 \\
Adjusted R square & .049 \\
Std Error of Estimate & 1.18 \\
Regression F ratio & 3.707 \\
P value & 0.000 \\
\hline
\end{tabular}

Table 4. Coefficients Indicating Relative Effects of Teacher Related Factors on Pupils' Achievement in Social Studies

\begin{tabular}{lcccc}
\cline { 2 - 5 } & $\begin{array}{c}\text { Standardized } \\
\text { coefficient Beta }\end{array}$ & T & P value & Remark \\
\hline Year of experience & -.177 & -3.549 & .000 & $\mathrm{~S}$ \\
Teacher qualification & .143 & 2.909 & .004 & $\mathrm{~S}$ \\
Formal authority & .110 & 1.013 & .312 & $\mathrm{NS}$ \\
Demonstration & -.095 & -1.013 & .312 & $\mathrm{NS}$ \\
Delegation & -.059 & -.766 & .444 & $\mathrm{NS}$ \\
Facilitation & -.053 & -.475 & .635 & $\mathrm{NS}$ \\
Assessment style & .022 & .371 & .711 & $\mathrm{NS}$ \\
Awareness of Assessment style & 0.008 & .128 & .898 & $\mathrm{NS}$ \\
\hline
\end{tabular}

Question Three: What are the relative effects of some teacher related factors: awareness level of assessment styles, assessment style, teacher personal characteristics (qualification, year of experience) teaching style on pupils achievement in Social Studies?

The relative effects of the teacher factors on pupils' Social Studies achievement in the order of absolute magnitude of standard Beta $(\beta)$ weights are presented in table 4 . Teachers' 
year of experience still contributed most, though inversely to pupils' achievement in Social Studies $(\beta=-.177 ; \mathrm{t}=-3.549 ; \mathrm{P}<.05)$. Next to year of experience of teachers is their educational qualifications which contributed significantly too to Pupils' achievement in Social Studies $(\beta=.143 ; \mathrm{t}=2.909 ; \mathrm{P}<.05)$. The magnitude of contributions of the other predictors to Social Studies achievement of pupils are:

Formal authority $(\beta=.110 ; \mathrm{t}=1.013 ; \mathrm{P}>.05)$,

Demonstration $(\beta=-.095, \mathrm{t}=-1.013 ; \mathrm{P}>.05)$,

Delegation $(\beta=-.059 ; \mathrm{t}=-.766 ; \mathrm{P}>.05)$

Facilitation $(\beta=-.053 ; \mathrm{t}=-.475 ; \mathrm{P}>.05)$

Assessment style $(\beta=-.022 ; \mathrm{t}=.371 ; \mathrm{P}>.05)$

Awareness of Assessment style $(\beta=.008 ; \mathrm{t}=.128 ; \mathrm{P}>.05)$

Only two predictors (teachers' year of experience and educational qualification) are still found to have significant relative effects on pupils' achievement in Social Studies.

\section{Discussion}

The results showed that Social Studies teachers engaged in one form or the other of teaching styles during their teaching. This is in congruence with the view Morgan, Kingston and Sproale (2005) who investigated the effects of different teaching styles on the teaching behaviours that influenced motivational climate and pupils' cognitive and affective responses in physical education.

The result also showed that teacher related factors (teacher awareness level of assessment style, teacher assessment style, teacher personal characteristics (qualification, year of experience and teaching styles were statistically significant to the dependent measure in Social Studies. These findings therefore supported Sanders and Rivers (1996) who found that the achievement gained from combination of teacher variables could be almost three times as large for African American Students as white students even when comparing students who start with similar achievement levels. To them the combination of variables could go a long way in enhancing students' performance. Also Rivkin, Hanushek and Kain (2005) found that teacher quality differences explained the largest portion of the variation in English and 
Mathematics which could equally be seen from the result of the study that variation existed but slightly in the result obtained from the core subjects investigated in the study.

Eight (8) variables were examined under teacher factors (level of awareness of assessment style, assessment style, teacher qualification, teacher year of experience, formal authority teaching style, Demonstrator teaching style, delegator teaching style, facilitator teaching style) indicated in table 4 . The general order of the magnitude of the contribution made to the dependent variable implied that only two predictors (Teachers' year of experience and educational qualification) are found to have significant relative effects on pupils' achievement in Social Studies.

These findings disagree with a wide range of findings on the relationship between years of teaching experience and student outcomes. Hanushek (1986) found that fewer than half of the 109 previous studies on the estimated effects of teacher experience showed that experience had any statistically significant effect on students' achievement, of those, 33 studies found that additional years of experience had a significant positive effect, but seven found that more experience actually had a negative impact on student achievement. Other studies show a stronger positive relationship between teacher experience and student outcomes in some, but not all, cases reviewed (e.g. Greenwald, Hedges, \& Laine 1996; Murnane, Willet, \& Levy, 1995).

It could also be plausibly deduced that a positive finding on experience as far as this study is concerned could be as a result of the tendency of newly employed teachers or young teachers -who wanted to ensure they do their best because they were still beginners in the profession. Thus, one can reasonably infer that the magnitude of the experience effect, should it exist, is not positively significant but negatively significant.

On the aspect of teacher educational qualifications, the result agreed with past findings that indicated positive relationships between teacher educational qualifications and student achievement, such studies include: Vogt (2001), Ehrenberg and Brewer (1994), and Summers and Wolfe, (1975). Thus, taken as a whole, the above authors suggest that measures of teacher academic qualifications represent one of the best predictors of teacher related factors. However, some authors (Goldhaber \& Brewer, 1997; Greenwald, Hedges, \& Laine, 1996) 
found that a teacher's advanced degree is not generally associated with increased student achievement.

\section{Conclusion}

The findings of this study have meaningful implications for classroom teachers, curriculum planners and educational evaluators. They revealed that teachers year of experience and teachers' educational qualification have a significant effect on pupils' achievement in Social Studies. Teachers that are young in terms of experience are found to be better in the teaching profession than those that have been long in the service. This might be as a result of diminishing effects, fatigue or boredom which may set in as a result of lack of challenge on the profession. The findings revealed that as vital as style of teaching is, formal authority and facilitation are the most commonly used teaching styles of primary school teachers'.

Based on the findings of the study, the following recommendations are made:

1. Workshops and seminars should be organized for teachers where they will be exposed to various teaching styles. This is necessary in order to assist them in knowing the teaching style that will lead to meaningful achievement of pupils in Social Studies.

2. Government should assist and encourage practising teachers to pursue knowledge that will aim at making them more productive in their respective subject areas. This can be possible by encouraging primary school teachers to upgrade their qualifications so that they will be familiar with modern ideas and practices in their subject areas.

\section{References}

Adegboye, A. O. (2003). The Genesis of the problems confronting mathematics education in Nigerian secondary schools and the solutions to the problems. Institute Journal of Studies in Education 1(5) 12 - 23.

Ajayi, A.O (1996). Quality improvement of teaching supervision and administration in primary schools. In A. O. Ajayi \& J. A. Akinwunmiju (Eds.) Personal performance and capacity building. Ibadan: The Department of Educational Management, University of Ibadan.

Beldon, D., Russonello, J., \& Stewart, K., (2004). Promoting excellence in teaching: Report of survey research of educators in Ohio. The Ohio Governor's Commission on 
Teaching Success. Retrieved May 6, 2007 from www.pateach.org/meetings/111105/pdf/goal1researcha.pdf

Brunner, J. S. (1963). Theories on instruction. London: Cambridge.

Bureau of Evaluative Studies and Testing, (2007). Classroom assessment techniques. Retrieved July 8, 2007 from http://www.ntlf.com/html/lib/bib/assess.htm.

Cuban, L. (1984). Know teachers who taught Constancy and change in American classrooms $(1890-1980)$. New York: Longman Inc.

Ehrenberg, R., \& Brewer, D. (1994). Do school and teacher characteristics matter? Evidence from High school and beyond. Retrieved online on March 10, 2008. http://www.centerforpubliceducation.org/site/c.kjJXJ5MPIwE/b.1510983/k.2A6A

Federal Republic of Nigeria, (2004). National Policy on Education. Lagos: Federal Ministry of Education.

Goldhaber, D.D., \& Brewer, D.J. (1997). Does teacher certification matter? High school teacher certification status and student achievement. Educational Evaluation and Policy Analysis, 22, 129-145.

Graham R. (1996). The Structural relationship between writing attitude and writing achievement in First and Third Grade students. Contemporary educational psychology 32(2), $516-536$.

Greenwald, R., Hedges, L.V., \& Laine, R.D. (1996). The effect of school resources on student achievement. Review of Educational Research, 66(3), 361-396.

Hanushek, E. (1986). The economics of schooling: Production and efficiency in public schools. Journal of Economic Literature, 24(3), 1141-78.

Hanushek, E. A.\& Raymond, M. E., (2003). Improving educational quality: How best to evaluate our schools? In Y. K. Kodrzycki, Eds., Education in the 21st Century: Meeting the Challenges of a Changing World, pp. 193 - 224. Boston: Federal Bank of Boston.

Lassa, P. N. (1996). Vision and mission of teacher education in Nigeria. Lead paper presented at the national conference on vision and mission of education in Nigeria organised by the NCCE at the NTI conference centre, Kaduna.

Lawani, L.A. (2004). A causal model of home and school factors as determinants of primary school pupils' achievement in English and Mathematics. Unpublished Ph.D Thesis. U.I 
Morgan, K. Kingston, K. \& Sproule, J. (2005). Effects of different teaching styles on the teacher behaviours that influence motivational climate and pupils' motivation in physical education. European Physical Education Review 11(3), 257 - 285.

Murname, L. F., Willet R. J. \& Levy J. B. (1995). Who will Teach? Policies that matters. Retrieved March 10, 2008, from http://en.wakipedia.org.d.dumitus.html

National Center for Education Statistics, (2005). Elementary/Secondary school teaching among recent college graduates:1994 and 2001: Statistical analysis report. Washington DC.: Department of Education, Institute of Education Sciences. 161.

Okwuanaso, S. I. \& Okeke B. C. (2005). Assessment challenges facing vocational education in Nigeria school system. A paper presented at the $31^{\text {st }}$ Annual conference of the international association for educational assessment (IAEA) at NICON Hilton Hotel Abuja, Nigerian on September 4th - 9th, 2005.

Osunde, A. U. (2005). The Relevance of assessment in instruction and learning in the school system. A paper presented at the $31^{\text {st }}$ annual conference of the international association for educational assessment (IAEA) at NICON Hilton Hotel Abuja, Nigerian on September 4th - 9th, 2005.

Osunde, A. U. \&Ughamadu, K. A. (2004). Improving the conduct of continuous assessment in schools. In A. O. Afemikhe \& J. D. Adewale (Eds), Issues in educational measurement and evaluation in Nigeria. Papers in honour of Professor Wole Falayajo Anyawu. Educational Research and Study Group, Institute of Education, University of Ibadan, Ibadan, Nigeria. 331 - 339 .

Primary Schools and Literacy, (2003). Teaching style is ingrained say researchers: Press Report of Research Financial Times, 20, June 2003.

Qualifications and Curriculum Authority (QCA), (2003). Assessment for Learning. Retrieved May 12, 2007 from http://www.qca.org.uk/ca/5-14/afl/

Rivkin, S.G., Hanushek, E.A., \& Kain, J.F. (2005). Teachers, schools, and academic achievement. Econometrica, 73(2), 417-458.

Sanders, W.L., \& Rivers, J.C. (1996). Cumulative and residual effects of teachers on future student academic achievement. Knoxville, TN: University of Tennessee ValueAdded Research and Assessment Center.

Summers, A. A. \& Wolfe B. E. (1975). Fifty reasons why student achievement gain does not mean teacher effectiveness. Journal of Personnel Evaluation in Education. 1(4), 345 $-363$. 
Ukeje, B.O. (1991). Need for qualified teachers. Nigerian journal of Education. Alvan Ikoku College of Education. Owerri. 1(1), 73.

Vogt, P. (2001). The impact of non-verbal communication on lexicon formation. In B. Kröse, M. De Rijke, G. Schreiber \& M. Van Someren (Eds.). Proceedings of the 13th Belgian/Netherlands Artificial Intelligence Conference, BNAIC'01. 